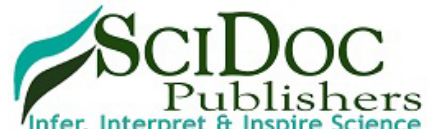

\author{
International Journal of Dentistry and Oral Science (IJDOS) \\ ISSN: $2377-8075$
}

\title{
Antimicrobial Efficacy Of Temporary And Permanent Denture Soft Lining Material Modified by Titanium - Dioxide Nanoparticles - An In-vitro Study
}

Research Article

Gowtham Neppala ${ }^{1}$, Subhabrata Maiti ${ }^{*}$, S Rajeshkumar ${ }^{3}$, Dhanraj Ganapathy ${ }^{4}$

${ }^{1}$ Saveetha Dental College and Hospitals, Saveetha Institute of Medical and Technical Sciences Saveetha University, Chennai-600077, Tamilnadu, India.

${ }^{2}$ Assistant Professor, Department of Prosthodontics And Implantology, Saveetha Dental College And Hospitals, Saveetha Institute Of Medical And Technical Sciences, Saveetha University, Chennai-600077, Tamilnadu, India.

${ }^{3}$ Associate Professor, Department of Pharmacology, Saveetha Dental College and Hospitals, Saveetha Institute of Medical and Technical Sciences Saveetha University, Chennai-600077, Tamilnadu, India.

${ }^{4}$ Professor and Head, Department of Prosthodontics And Implantology, Saveetha Dental College And Hospitals, Saveetha Institute Of Medical And Technical Sciences, Saveetha University, Chennai-600077, Tamilnadu, India.

\section{Abstract}

Tissue conditioners are soft denture liners which are commonly applied to the tissue surface of a denture.Tissue conditioners are soft denture liners which are commonly applied to the fitting surface of a denture.Soft liners absorb the masticatory impact and act as a 'shock absorber'.

Aim: The aim of present study is assessment the effect of addition of Titanium-dioxide Nanoparticles to a soft liner on would inhibit the growth of Microbes in Permanent and Temporary Softliners.

Materials and Methods: The study done is an in vitro experimental design.Titanium NP are incorporated into Temporary and permanent denture soft liner and these specimen are kept in the Blood Agar media for 3 microorganisms namely Candida albicans, Streptococcus mutans, Lactobacillus and all the culture plates are incubated for 24 hours under Room Temperature and Zone of Inhibition is calculated in the Agar media using measuring tape.

Results: The zone of inhibition in Lactobacillus was maximum for permanent soft liner with NP (20.33 \pm 1.528$)$ and minimum in Temporary soft liner with NP $(10.67 \pm 0.577)$, the mean difference among groups was statistically significant $(\mathrm{p}<0.05)$.

Conclusion: Permanent and Temporary soft liners with Titanium Nanoparticles showed antimicrobial efficacy against Lactobacilli.

Keywords: Denture Liners; Nanoparticles; Titanium Dioxide; Denture Stomatitis.

\section{Introduction}

Relining a complete denture is required less oftenly due to soft tissue changes arising from bone resorption. Tissue conditioners are soft denture liners which are commonly applied to the fitting surface of a denture. Soft liners absorbs the masticatory impact and act as a 'shock absorber'. Some Patients suffer from chronic pain, soreness or discomfort due to prolonged contact between the rigid denture base materials and the underlying tissues; usually in patients with sharp, thin, or heavily resorbed ridges or those with severe undercuts. Denture relining materials absorb masticatory force and distribute to underlying alveolar ridge widely and enhance patient comfort [1]. Relining a denture is performed directly in the mouth using auto-polymerizing denture relining materials and indirectly in the laboratory by heat-cured denture relining materials $[1,2]$. Denture relining materials are used in sensitive patients and help in conditioning tissue and limit the traumatic effect of denture causing cushioning effect [3]. Denture relining material distribute the loads transferred to soft tissues during motion in Immediate denture. Soft lining materials are contaminated in the oral environment and are not possible to clean (or) brush effectively [4]. Denture relining materials are hard to maintain and failure of cleaning between denture base and liners creates an environment which renders bacterial colonization and also com-

\author{
*Corresponding Author \\ Subhabrata Maiti, \\ Assistant Professor, Department of Prosthodontics And Implantology, Saveetha Dental College And Hospitals, Saveetha Institute Of Medical And Technical Sciences, Saveetha \\ University, Chennai-600077, Tamilnadu, India. \\ Tel: 9007862704 \\ E-mail: drsubhoprostho@gmail.com \\ Received: November 12, 2020 \\ Accepted: November 27, 2020 \\ Published: December 03, 2020 \\ Citation: Gowtham Neppala, Subhabrata Maiti, S Rajeshkumar, Dhanraj Ganapathy. Antimicrobial Efficacy Of Temporary And Permanent Denture Soft Lining Material Modified
} by Titanium - Dioxide Nanoparticles - An In vitro Study. Int J Dentistry Oral Sci. 2020;S5:02:005:21-26. doi: http://dx.doi.org/10.19070/2377-8075-SI02-05005

Copyright: Subhabrata Maiti 2020 . This is an open-access article distributed under the terms of the Creative Commons Attribution License, which permits unrestricted use, distribution and reproduction in any medium, provided the original author and source are credited. 
promise the durability of the soft liner.A number of problems associated with the use of reliners have been reported, such as porosity, loss of softness, debonding from the denture base, rough surface, color changes, colonization by microorganisms and poor tear strength [5].

Denture disinfectant agents are Chlorhexidine gluconate,Sodium hypochlorite, Hydrogen peroxide can be used against accumulation of microbes [6]. Incorporation of Nanoparticles into Denture Softliner and gives positive results on In vitro growth inhibition of Microorganisms [7].

Antifungal activity of Denture soft liner modified using silver Nanoparticles should be capable of preventing colonisation of Candida albicans and denture Soft Linings [7-10]. Antifungal Efficacy and the Mechanical properties of softliner against Candida and Incorporation of Garlic and Neem concluded that Neem and Garlic added to Softliner had an Inhibitory effect on Candida albicans.

There are numerous studies assessing Antimicrobial activity of Denture Soft Lining Material, and there are few studies regarding the effect of Titanium Nanoparticles in dentistry that too on Temporary and Permanent Denture Softliner [10, 11]. A study says that Direct contact with friable tissue when added upon by Silver Nanoparticles shows change of bacterial growth over Soft Lining Material and there is remarkable amount of Microbial reduction $[12,13]$.
Micro porosities and roughness in the denture surface will lead to adherence of Candida albicans and formation of the colonies on the fitting surface of the denture. These microorganisms have to be removed by mechanical or chemical cleansing;however in some situations, there cannot be completely removed from the denture surfaces Polymethylmethacrylate (PMMA) is the most common material used in the fabrication of removable complete or Partial denture prosthesis [14].

The aim of present study is assessment the effect of addition of Titanium-dioxide Nanoparticles to a soft liner on would inhibit the growth of Microbes in Permanent and Temporary Softliners.

\section{Materials and Methods}

The study done was an in vitro, experimental design.

\section{Preparation of Nanoparticles}

100 millimolar of Titanium-dioxide Nanoparticles in $100 \mathrm{ml}$ of Serratia nematodiphiles broth and kept in shaker for 24 hours and purified by centrifugation and Dried.

\section{Specimen Preparation}

Preparation of Temporary soft liner: Soft liner models are prepared using the wax sheet which is cut into $1 \mathrm{x} 1 \mathrm{~cm}$ and mould is prepared and thin section of soft liner with $1 \mathrm{~cm}$ thickness is fabricated and are separated GC soft liner (GC soft liner, GC

Figure 1. TEM image of TiO2 nanoparticles.

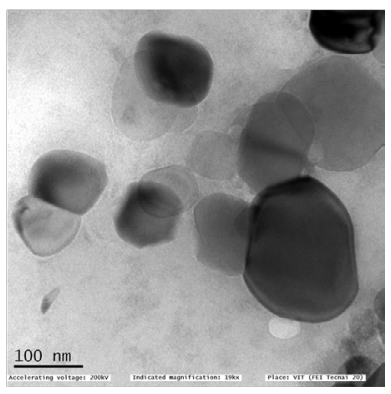

Figure 2. Temporary soft liner with NP towards left and Temporary soft liner without NP.
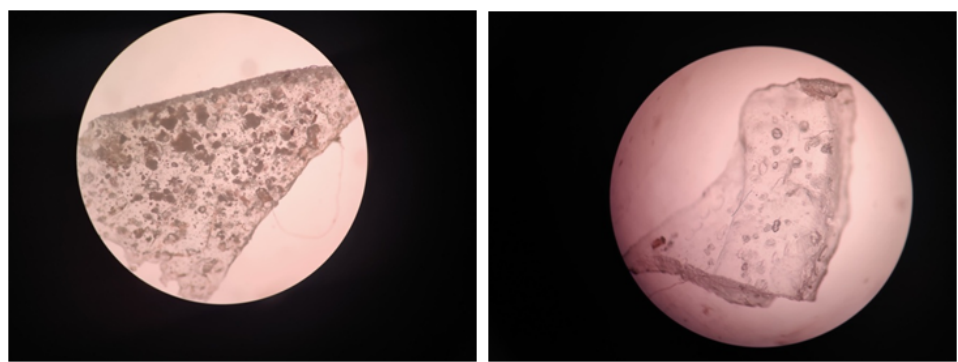

Figure 3. Permanent soft liner with NP towards left and Permanent soft liner without NP.
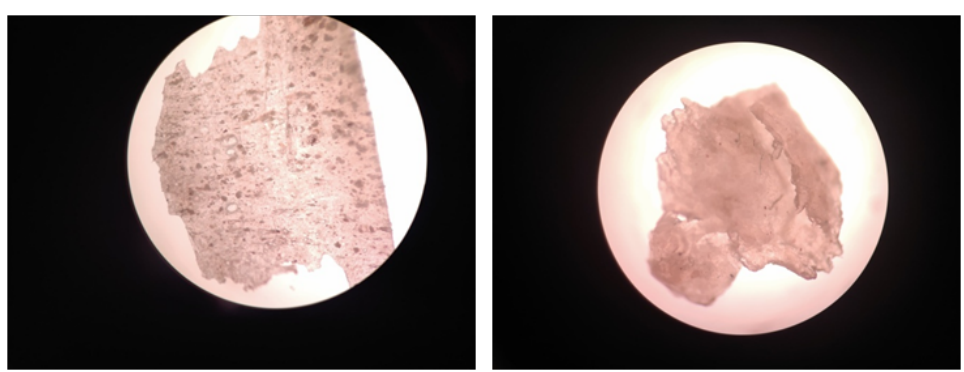
Corporation, Tokyo, Japan).

Preparation of Permanent Softliner: Permanent soft liner are prepared using Permanent soft liner by Molloplast (DETAX GmbH \& Co. KGCarl-Zeiss-Str. 476275 Ettlingen Germany)An index of the wax sheet measuring $1 \mathrm{x} 1 \mathrm{~cm}$ and thickness of $1 \mathrm{~cm}$ was made using polyvinyl siloxane materials on which soft liner material was added.Three part dental Flask was used for Flasking the fabricated soft liner using dental stone. Reverse flaking technique was followed by wax elimination. Square shaped mould space was created where Heat-activated Permanent Denture Soft Lining Material and cured according to manufacturer's Instructions to obtain soft liner discs.

Adding of Titanium Nanoparticles: For Temporary soft liner for $2.2 \mathrm{~g} / 1.8 \mathrm{~g}$ liquid GC soft liner and $1 \mathrm{mg}$ of Titanium dioxide Nanoparticles is added and allow to Heatcuring according to manufacturer's instructions and Titanium dioxide Impregnated Permanent soft liner is removed.Impregnated Nanoparticles were checked under microscope.

Sterilization of Specimen: The specimens were handled carefully which includes the utilization of latex gloves for all phases of Investing dewaxing, packing and retrieval of specimens. All the specimens are kept in UV chamber for 2 hours.

Preparation of AgarMedium: The specimens were prepared in a petri dish for culture media are prepared under aseptic conditions. After preparing they are kept in UV chamber for sterilization under Aseptic conditions for one hour. Blood Agar preparation was done for 3 microorganisms namely Candida albicans, Streptococcus mutans, Lactobacillus and kept in Laminar air flow chamber for sterilization.

\section{Antimicrobial Test}

The prepared Titanium Nanoparticles are incorporated into softliner are inoculated into Agar plates under aseptic conditions and grouped into 3 groups and 4 samples in each group.

Each group consists of one microbe namely Streptococcus mutans, Lactobacillus and Candida albicans and each group is having 4 samples namely 1)Temporary soft liner without Nanop.

articles 2)Temporary soft liner with Nanoparticles 3)Permanent soft liner without Nanoparticles 4)Permanent soft liner with $\mathrm{Na}$ noparticles same test was performed 3 times to eliminate bias.All the culture plates are incubated for 24 hours under Room Temperature and Zone of Inhibition is calculated using measuring tape.

\section{Statistical Analysis}

Descriptive statistics was used to evaluate zone of inhibition of different microbes in the culture media. One Way Anova and Tukey HSD Post hoc test was performed and the $\mathrm{p}$ value was determined to evaluate the significance of the variables. The correlation between different groups about zone of inhibition is evaluated and statistics were carried using SPSS Software version 23.0 by IBM India. The results were obtained in the form of tables and graphs.

\section{Results}

This study shows addition of Titanium Nanoparticles to temporary and permanent soft liner shows antimicrobial action in different culture media after 24 hours of incubation in the petri dishes that are separated and see for changes for the zone of inhibition in streptococcus was maximum for permanent soft liner with NP $(18.33 \pm 1.528)$ and minimum in Temporary soft liner with NP (10.00 \pm 0$)$, the mean difference among groups was statistically significant $(\mathrm{p}<0.05)$ followed by The zone of inhibition in Lactobacillus was maximum for permanent soft liner with NP $(20.33 \pm 1.528)$ and minimum in Temporary soft liner with NP $(10.67 \pm 0.577)$, the mean difference among groups was statistical-

Figure 4. Zone of inhibition seen in Agar by Streptococcus mutans in Permanent soft liner.

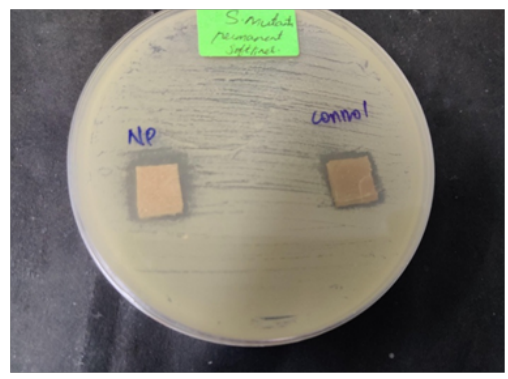

Figure 5. Zone of inhibition seen in Agar by Lactobacillus in Permanent soft liner.

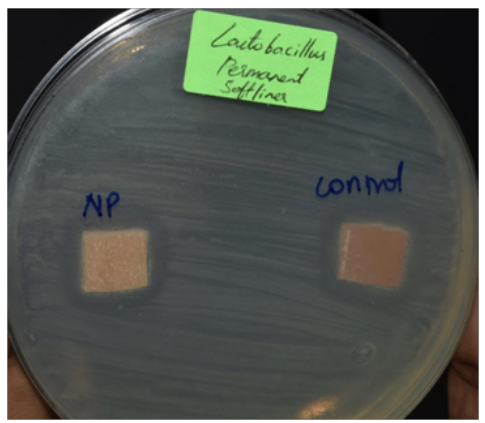


Table 1. Comparison of Zone of inhibition against different microbes among four group 1)Temporary soft liner without Nanoparticles 2)Temporary soft liner with Nanoparticles 3)Permanent soft liner without Nanoparticles 4)Permanent soft liner with Nanoparticles.

\begin{tabular}{|c|c|c|c|c|c|}
\hline Microbes & Group & Mean \pm SD & $\mathrm{df}$ & $\mathrm{F}$ & $\mathrm{p}$-value \\
\hline $\begin{array}{l}\text { Streptococcus } \\
\text { mutans }\end{array}$ & $\begin{array}{l}\text { 1) Temporary soft liner without NP } \\
\text { 2) Temporary soft liner with NP } \\
\text { 3) Permanent soft liner without NP } \\
\text { 4)Permanent soft liner with NP }\end{array}$ & $\begin{array}{c}10.67 \pm 0.557 \\
10.00 \pm 0 \\
14.33 \pm 1.528 \\
18.33 \pm 1.528\end{array}$ & 3 & 35.378 & $0.001 *$ \\
\hline Lactobacillus & $\begin{array}{l}\text { 1) Temporary soft liner without NP } \\
\text { 2) Temporary soft liner with NP } \\
\text { 3) Permanent soft liner without NP } \\
\text { 4)Permanent soft liner with NP }\end{array}$ & $\begin{array}{l}11.33 \pm 0.577 \\
10.67 \pm 0.577 \\
17.33 \pm 1.155 \\
20.33 \pm 1.528 \\
\end{array}$ & 3 & 61.00 & $0.001 *$ \\
\hline Candida albicans & $\begin{array}{l}\text { 1) Temporary soft liner without NP } \\
\text { 2) Temporary soft liner with NP } \\
\text { 3) Permanent soft liner without NP } \\
\text { 4)Permanent soft liner with NP }\end{array}$ & $\begin{array}{l}10.67 \pm 0.577 \\
10.33 \pm 0.577 \\
10.33 \pm 0.577 \\
10.33 \pm 0.577\end{array}$ & 3 & 0.250 & 0.859 \\
\hline
\end{tabular}

*significant $\mathrm{p}<0.05 \mathrm{p}$ value derived from one way ANOVA test.

Table 2. Pairwise comparison between four groups namely Temporary soft liner without Nanoparticles, Temporary soft liner with Nanoparticles, Permanent soft liner without Nanoparticles, Permanent soft liner with Nanoparticles based on zone of inhibition on streptococcus and lactobacillus.

\begin{tabular}{|c|c|c|c|c|}
\hline Microbes & Groups & MD & SE & p-value \\
\hline \multirow{6}{*}{$\begin{array}{c}\text { Streptococ- } \\
\text { cus } \\
\text { mutans }\end{array}$} & $\begin{array}{l}\text { Temporary soft liner without NP } \\
\text { (vs)Temporary soft liner with NP }\end{array}$ & 0.667 & 0.913 & 0.882 \\
\hline & $\begin{array}{l}\text { Temporary soft liner without NP } \\
\text { (vs)Permanent soft liner without NP }\end{array}$ & 3.667 & 0.913 & $0.016^{*}$ \\
\hline & $\begin{array}{l}\text { Temporary soft liner without NP } \\
\text { (vs)Permanent soft liner with NP }\end{array}$ & 7.667 & 0.913 & $0.001 *$ \\
\hline & $\begin{array}{c}\text { Temporary soft liner with NP(vs)Permanent soft liner without NP } \\
\text { Temporary soft liner with NP }\end{array}$ & 4.333 & 0.913 & $0.006^{*}$ \\
\hline & (vs)Permanent soft liner with NP & 8.333 & 0.913 & $0.001 *$ \\
\hline & Permanent soft liner without NP (vs)Permanent soft liner with NP & 4 & 0.913 & $0.010^{*}$ \\
\hline \multirow[t]{6}{*}{$\begin{array}{l}\text { Lactobacil- } \\
\quad \text { lus sp }\end{array}$} & $\begin{array}{l}\text { Temporary soft liner without NP } \\
\text { (vs)Temporary soft liner with NP }\end{array}$ & 0.667 & 0.850 & 0.86 \\
\hline & $\begin{array}{l}\text { Temporary soft liner without NP } \\
\text { (vs)Permanent soft liner without NP }\end{array}$ & 6.000 & 0.850 & $0.001 *$ \\
\hline & $\begin{array}{l}\text { Temporary soft liner without NP } \\
\text { (vs)Permanent soft liner with NP }\end{array}$ & 9.000 & 0.850 & $0.001 *$ \\
\hline & $\begin{array}{c}\text { Temporary soft liner with NP(vs)Permanent soft liner without NP } \\
\text { Temporary soft liner with NP }\end{array}$ & 6.667 & 0.850 & $0.001^{*}$ \\
\hline & (vs)Permanent soft liner with NP & 9.667 & 0.850 & $0.001 *$ \\
\hline & Permanent soft liner without NP (vs)Permanent soft liner with NP & 3.000 & 0.850 & $0.032 *$ \\
\hline
\end{tabular}

* The mean difference is significant at 0.05 level $\mathrm{p}$-value was derived from Tukey HSD Post hoc test significant $\mathrm{p}<0.05$.

ly significant $(\mathrm{p}<0.05)$ and in candida the zone of inhibition was maximum for Temporary soft liner without NP $(10.67 \pm 0.577)$ and minimum in Temporary soft liner with Nanoparticles, Permanent soft liner without Nanoparticle and Permanent soft liner with Nanoparticle groups $(10.33 \pm 0.577)$, the mean difference among groups was statistically insignificant $(\mathrm{p}>0.05)$.

For pairwise Comparisons the mean difference between all the groups are statistically significant $(\mathrm{p}<0.05)$, except between group 1 and $2(\mathrm{p}>0.05)$ on both the micro organism (Streptococcus, Lactobacillus).

\section{Discussion}

In the present study, the addition of Titanium Nanoparticles to Tissue conditioner yielded bactericidal and fungicidal properties for three reference strains, Lactobacillus, $S$. mutants and C. albicans of this $S$. mutants has been associated closely with the pathogenesis of dental caries, which is of limited clinical significance for denture wearers [15]. However, extensive plaque formation on denture might also contribute to the decay of residual natural teeth in over denture patients and also causes inflammation of gingival tissue adjacent to the denture.Candida albicans can be regularly isolated, suggesting a pathogenic association between bacteria 
and fungi related with denture stomatitis. In recent years, various nanoparticles have been reported to display good biological activities [16]. Amongst them, TiO2 nanoparticles have oxidative and hydrolysis properties. As a photocatalyst, it can improve the efficiency of electrolytically splitting water into hydrogen and oxygen which can produce electricity in nanoparticles form. When these nanoparticles are exposed to ultraviolet (UV) light, they become increasingly hydrophilic [17]. It has been reported that surface roughness is a vital property because of its impact on microbial adhesion. For this reason, if a Soft Liner Material incorporated with Antifungal drugs (or) Antimicrobials has to be developed to interface on the denture surface to avoid colonization in the Denture [18]. Roughness in the fitting surface of denture base generally promote initial microbial adhesion as the denture plaque matures on the fitting surface it is associated with a protective biofilm, and biofilm-related chronic infections, such as candidiasis, are inherently difficult to treat and fully eradicate with routine therapy. As elderly denture wearer's ability to perform oral self care declines, a demand for a simple, effective and preventive denture care system is required.An agent with a modest antifungal effect, although not biocidal, may even be desirable to decrease the potential side effect of various agents [19]. It is reported that $\mathrm{Ag}$ and silver-based compounds are highly toxic to prokaryotic cells showing strong biocidal effects as bacteria species, while Ag showed less effect on eukaryotic cells such as mold and yeasts [2022]. The microbial investigation conducted on this study confirms that the released concentrations of the Antimicrobial agents from Soft Lining material were able to induce an Antimicrobial effect on Agar culture. These specimens maintain high osteoblastic cell (SaOS-2) viability and induce mild but statistically significant antibacterial activity on P. gingivalis and P. intermedia strains, which is inline with the low AgNP concentrations detected [23, 24].Obturator wearers with oro-nasal communication often present with prosthesis-induced stomatitis because of Candida albicans colonization on the acrylic nasal surfaces by adding silver Nanoparticles it shows some Anti-microbial feature [25-28]. Urban et al., [29] also studied particle size and distribution of antifungal agents in a plasticized matrix of tissue conditioners. For example, nanoparticles have high surface area and reactivity [30] hence likely to accelerate the drug release.

The advantages of soft liners include greater range of overdenture movement, energy absorption, and equal force distribution to the implants and edentulous ridge $[31,32]$. The soft liner encircles the bar and completely obturates the spaces around it. The continuous cleaning of the bar and abutments by soft liners during insertion and removal of the denture prevents plaque accumulation around the bar regardless of oral hygiene practice [33].

\section{Limitations and Future Scope}

This particular study lacks an oral environment furthermore changes in hardness of denture base after incorporation of Titanium Nanoparticle.Further more confirmation with experiments conducted under in vivo conditions.

With the basic limitations of the study design, generalizability is a possibility with further accumulation of evidence in this regard. However, within the limitations of the present study it could be concluded that addition of Titanium nanoparticles to softliner, as an adjunct, it is found effective and safe on further research would be considered as a potential "adjunct" along with the standard care in the to overcome the side effects of synthetic drugs, especially in this era of ever advancing clinical dentistry.It has various clinical significances in implant dentistry,Immediate denture and Myofunctional prosthesis etc., and can make the outcome more advanced and towards the ultimate success.

\section{Conclusion}

Within the limits of this study it is presumed that both Permanent and Temporary both soft liner have there own mild antibacterial activity and Titanium Nanoparticles can show Antimicrobial efficacy in groups Lactobacillus and No (or) minimum efficacy in Candida and Streptococcus mutans.Addition of Titanium $\mathrm{Na}$ noparticles as an adjunct,is found to be effective and on further research it would be considered as a potential adjunct along with the standard care in the management of denture stomatitis to overcome side effects of synthetic drugs.

\section{References}

[1]. Kawano F, Tada N, Nagao K, Matsumoto N. The influence of soft lining materials on pressure distribution. J Prosthet Dent. 1991 Apr;65(4):567-75. Pubmed PMID: 2066898.

[2]. Basker RM, Davenport JC, Thomason JM. Prosthetic treatment of the edentulous patient. John Wiley \& Sons; 2009 Feb 10:328.

[3]. Saravanan M, Kumar A, Padmanabhan TV, Banu F. Viscoelastic properties and antimicrobial effects of soft liners with silver zeolite in complete dental prosthesis wearers: an in vivo study. Int J Prosthodont. 2016 MayJun;28(3):265-9.Pubmed PMID: 25965641.

[4]. Dimiou AM, Michalakis K, Pissiotis A. Influence of thickness increase of intraoral autopolymerizing hard denture base liners on the temperature rise during the polymerization process. J Prosthet Dent. 2014 Jun;111(6):51220.Pubmed PMID: 24360010.

[5]. Kawano F, Dootz ER, Koran A 3rd, Craig RG. Comparison of bond strength of six soft denture liners to denture base resin. J Prosthet Dent. 1992 Aug;68(2):368-71.Pubmed PMID: 1501192.

[6]. Kasuga Y, Takahashi H, Akiba N, Minakuchi S, Matsushita N, Hishimoto M. Basic evaluation on physical properties of experimental fluorinated soft lining materials. Dent Mater J. 2011;30(1):45-51.Pubmed PMID: 21282889.

[7]. Bail M, Jorge JH, Urban VM, Campanha NH. Surface roughness of acrylic and silicone-based soft liners: in vivo study in a rat model. J Prosthodont. 2014 Feb;23(2):146-51.Pubmed PMID: 23875942.

[8]. McCullough MJ, Ross BC, Reade PC. Candida albicans: a review of its history, taxonomy, epidemiology, virulence attributes, and methods of strain differentiation. Int J Oral Maxillofac Surg. 1996 Apr;25(2):136-44.Pubmed PMID: 8727588.

[9]. Verran J, Maryan CJ. Retention of Candida albicans on acrylic resin and silicone of different surface topography. J Prosthet Dent. 1997 May;77(5):5359.Pubmed PMID: 9151275.

[10]. Kumar SM, Kumar VA, Natarajan P, Sreenivasan G. Antifungal Efficacy and the Mechanical Properties of Soft Liners against Candida albicans after the Incorporation of Garlic and Neem: An In vitro Study. J Int Soc Prev Community Dent. 2018 May-Jun;8(3):212-217.Pubmed PMID: 29911057.

[11]. Pokrowiecki R, Zaręba T, Szaraniec B, Pałka K, Mielczarek A, Menaszek E, et al. In vitro studies of nanosilver-doped titanium implants for oral and maxillofacial surgery. Int J Nanomedicine. 2017 Jun 6;12:4285-4297.Pubmed PMID: 28652733.

[12]. Barua DR, Basavanna JM, Varghese RK. Efficacy of Neem Extract and Three Antimicrobial Agents Incorporated into Tissue Conditioner in Inhibiting the Growth of C. Albicans and S. Mutans. J Clin Diagn Res. 2017 May;11(5):ZC97-ZC101.Pubmed PMID: 28658918.

[13]. Nam KY. In vitro antimicrobial effect of the tissue conditioner containing silver nanoparticles. J Adv Prosthodont. 2011 Mar 1;3(1):20-4.

[14]. Przybyłowska D, Mierzwińska-Nastalska E, Swoboda-Kopeć E, Rubinsztajn R, Chazan R. Potential respiratory pathogens colonisation of the denture plaque of patients with chronic obstructive pulmonary disease. Gerodontology. 2016 Sep;33(3):322-7.Pubmed PMID: 25393518.

[15]. Urban VM, Lima TF, Bueno MG, Giannini M, Arioli Filho JN, de Almeida $\mathrm{AL}$, et al. Effect of the addition of antimicrobial agents on Shore A hardness 
and roughness of soft lining materials. J Prosthodont. 2015 Apr;24(3):20714.Pubmed PMID: 25082183.

[16]. Pal S, Tak YK, Song JM. Does the antibacterial activity of silver nanoparticles depend on the shape of the nanoparticle? A study of the gramnegative bacterium Escherichia coli. Appl. Environ. Microbiol. 2007 Mar $15 ; 73(6): 1712-20$.

[17]. Fujishima A, Rao TN, Tryk DA. Titanium dioxide photocatalysis. J. Photochem. Photobiol. C: Photochemistry reviews. 2000 Jun 29;1(1):1-21.

[18]. Chladek G, Kasperski J, Barszczewska-Rybarek I, Zmudzki J. Sorption, solubility, bond strength and hardness of denture soft lining incorporated with silver nanoparticles. Int J Mol Sci. 2012 Dec 27;14(1):563-74.Pubmed PMID: 23271371

[19]. de Oliveira RC, de Foggi CC, Teixeira MM, da Silva MD, Assis M, Francisco EM, et al. Mechanism of Antibacterial Activity via Morphology Change of $\alpha$-AgVO3: Theoretical and Experimental Insights. ACS Appl Mater Interfaces. 2017 Apr 5;9(13):11472-11481.Pubmed PMID: 28291327. https:// pubmed.ncbi.nlm.nih.gov/28291327/

[20]. Zhao G, Edward Stevens S, Jr. Biometals .1998;11:27-32.

[21]. Feng QL, Wu J, Chen GQ, Cui FZ, Kim TN, Kim JO. A mechanistic study of the antibacterial effect of silver ions on Escherichia coli and Staphylococcus aureus. J Biomed Mater Res. 2000 Dec 15;52(4):662-8.Pubmed PMID: 11033548

[22]. Zelicoff JT, Thomas P, editors. Immunotoxicology of environmental and occupational metals. CRC Press. 1998 Feb 20:374.

[23]. Christensen M, Rungby J, Mogensen SC. Effects of selenium on toxicity and ultrastructural localization of mercury in cultured murine macrophages. Toxicol Lett. 1989 Jun;47(3):259-70.Pubmed PMID: 2749770.

[24]. Guzman M, Dille J, Godet S. Synthesis and antibacterial activity of silver nanoparticles against gram-positive and gram-negative bacteria. Nanomedicine: Nanotechnology, Biology and Medicine. 2012 Jan 1;8(1):37-45.

[25]. Acosta-Torres LS, López-Marín LM, Nunez-Anita RE, Hernández-Padrón
G, Castaño VM. Biocompatible metal-oxide nanoparticles: nanotechnology improvement of conventional prosthetic acrylic resins. J. Nanomater. 2011 Jan 1;2011:1-8.

[26]. Acosta-Torres LS, Mendieta I, Nuńez-Anita RE, Cajero-Juárez M, Castaño VM. Cytocompatible antifungal acrylic resin containing silver nanoparticles for dentures. Int J Nanomedicine. 2012;7:4777-86.Pubmed PMID: 22969297.

[27]. Elsaka SE, Hamouda IM, Swain MV. Titanium dioxide nanoparticles addition to a conventional glass-ionomer restorative: influence on physical and antibacterial properties. J Dent. 2011 Sep;39(9):589-98.Pubmed PMID: 21651955.

[28]. Muñoz-Bonilla A, Fernández-García M. Polymeric materials with antimicrobial activity. Prog. Polym. Sci. 2012 Feb 1;37(2):281-339.

[29]. Urban VM, Seó RS, Giannini M, Arrais CA. Superficial distribution and identification of antifungal/antimicrobial agents on a modified tissue conditioner by SEM-EDS microanalysis: a preliminary study. J Prosthodont. 2009 Oct;18(7):603-10.Pubmed PMID: 19515168.

[30]. Khurshid Z, Zafar M, Qasim S, Shahab S, Naseem M, AbuReqaiba A. Advances in nanotechnology for restorative dentistry. Materials. 2015 Feb;8(2):717-31.

[31]. Kiat-Amnuay S, Khan Z, Gettleman L. Overdenture retention of four resilient liners over an implant bar. J Prosthet Dent. 1999 May;81(5):568-73. Pubmed PMID: 10220661.

[32]. Adrian ED, Krantz WA, Ivanhoe JR. The use of processed silicone to retain the implant-supported tissue-borne overdenture. J Prosthet Dent. 1992 Feb;67(2):219-22.Pubmed PMID: 1538330.

[33]. Elsyad MA, Shoukouki AH. Resilient liner vs. clip attachment effect on peri-implant tissues of bar-implant-retained mandibular overdenture: a 1-year clinical and radiographical study. Clin Oral Implants Res. 2010 May;21(5):473-80.Pubmed PMID: 20443800. 